\title{
Studies Regarding the Main Compositional Parameters and Some Volatile Compounds in Spirits from Iaşi Vineyard
}

\author{
Lucia-Cintia COLIBABA ${ }^{1}$, Stefan TUDOSE-SANDU-VILLE ${ }^{1}$, Camelia LUCHIAN ${ }^{1}$, Andreea POPIRDA ${ }^{1}$, \\ Marius NICULAUA², Valeriu V. COTEA ${ }^{1 *}$ \\ ${ }^{1}$ Faculty of Horticulture, University of Agricultural Sciences and Veterinary Medicine, 3 Mihail \\ Sadoveanu Avenue, 700490 Iași, Romania. \\ ${ }^{2}$ Oenological Research Center - Iasi Branch of Romanian Academy, 8 Carol I Boulevard, 700505 Iaşi, \\ Romania \\ *Corresponding author, e-mail: vcotea@uaiasi.ro
}

Bulletin UASVM Horticulture 74(2)/ 2017

Print ISSN 1843-5254, Electronic ISSN 1843-5394

DOI:10.15835/buasvmcn-hort: 0013

\begin{abstract}
The distillates obtained from wine, both raw and aged, are highly appreciated alcoholic beverages due to the refinement and fineness that characterizes them. Romania's viticultural conditions are very favourable for these products - which in the last centuries have made regions such as Cognac and Armagnac in France famous. In Romania the aged distillate of wine is called "vinars" and in the Republic of Moldova it is named "divin". This study analyses how the main compositional parameters and volatile compounds are influenced by the raw material wine, distillation technology, distillation steps, removal of the lower-quality fractions (heads and tails). The raw material used to make the distillates was a mixture of two wines of Fetească albă and Fetească regală, harvest of 2015, from Iasi vineyard. The proposed experimental protocol consisted of the double distillation of a volume of $1000 \mathrm{~L}$ of raw material. For the distillation, a simple copper distillery with a deflector was used. From each $10 \mathrm{~L}$ of distillate obtained, samples were taken and analysed via gas-chromatography.

In the first and second distillation, the largest amounts of acetic acid are found in the head. The highest concentrations of octanoic acid are recorded in tails, as does hexanoic acid. The product obtained after the first distillation recorded an average alcoholic strength of $33.5 \%$ vol, which increased after the second distillation, so that the final distillate has an alcoholic strength of $58.5 \%$ vol. Concerning the acid profile, the following can be concluded: Acetic acid can be considerably diminished with the removal of the head fractions; Octanoic, hexanoic and decanoic acids fall into the class of short chain fatty acids, can affect the organoleptic qualities but are easily esterify the resulting compounds giving pleasing odour; aging in oak or mulberry wood barrels of crude distillates to achieve the maximum potential is recommended.
\end{abstract}

Keywords: spirits, volatile compounds, wine-base

\section{INTRODUCTION}

Distillation is an ancient process, used by Arabs, Europeans and even Chinese during the 12th century. Fractional distillation was developed by Taddeo Alderotti in the 13th century $(6,7)$ The production method was written in code, suggesting that it was being kept secret. As a result of the different boiling temperatures of various volatile substances found in wine, it has been decided that three fractions can be separated from the distillation (9).

The heads - the first fraction - consists of volatile components with boiling points ranging from $29^{\circ} \mathrm{C}$ to $77^{\circ} \mathrm{C}$. The total does not exceed $1-2 \%$ of the volume for the distillate, generally having an unpleasant odour. The second fraction of the distillate is obtained over a longer time ( 6 - 8 hours), volatile components having boiling 
Tab. 1. Experimental distillate variants taken into analysis

\begin{tabular}{|c|c|}
\hline Code & Description \\
\hline $\mathrm{c} 1-10 \mathrm{~L}$ & First fill, $10 \mathrm{~L}$ of obtained distillate \\
\hline c1-20L & First fill, $20 \mathrm{~L}$ of obtained distillate \\
\hline $\mathrm{c} 1-30 \mathrm{~L}$ & First fill, $30 \mathrm{~L}$ of obtained distillate \\
\hline c1-40L & First fill, $40 \mathrm{~L}$ of obtained distillate \\
\hline $\mathrm{c} 1-50 \mathrm{~L}$ & First fill, $50 \mathrm{~L}$ of obtained distillate \\
\hline c1-60L & First fill, $60 \mathrm{~L}$ of obtained distillate \\
\hline c1-70L & First fill, $70 \mathrm{~L}$ of obtained distillate \\
\hline $\mathrm{c} 2-80 \mathrm{~L}$ & Second fill, $80 \mathrm{~L}$ of obtained distillate \\
\hline c2-90L & Second fill, $90 \mathrm{~L}$ of obtained distillate \\
\hline $\mathrm{c} 2-100 \mathrm{~L}$ & Second fill, $100 \mathrm{~L}$ of obtained distillate \\
\hline $\mathrm{c} 2-110 \mathrm{~L}$ & Second fill, $110 \mathrm{~L}$ of obtained distillate \\
\hline $\mathrm{c} 2-120 \mathrm{~L}$ & Second fill, $120 \mathrm{~L}$ of obtained distillate \\
\hline c3-130L & Third fill, $130 \mathrm{~L}$ of obtained distillate \\
\hline c3-140L & Third fill, $140 \mathrm{~L}$ of obtained distillate \\
\hline c3-150L & Third fill, $150 \mathrm{~L}$ of obtained distillate \\
\hline c3-160L & Third fill, $160 \mathrm{~L}$ of obtained distillate \\
\hline c3-170L & Third fill, $170 \mathrm{~L}$ of obtained distillate \\
\hline c3-180L & Third fill, $180 \mathrm{~L}$ of obtained distillate \\
\hline c4-190L & Fourth fill, $190 \mathrm{~L}$ of obtained distillate \\
\hline c4-200L & Fourth fill, $200 \mathrm{~L}$ of obtained distillate \\
\hline c4-210L & Fourth fill, $210 \mathrm{~L}$ of obtained distillate \\
\hline c4-220L & Fourth fill, $220 \mathrm{~L}$ of obtained distillate \\
\hline c4-230L & Fourth fill, $230 \mathrm{~L}$ of obtained distillate \\
\hline $\mathrm{c} 1^{\prime}-10 \mathrm{~L}$ & First fill for second distillation, $10 \mathrm{~L}$ de of obtained distillate \\
\hline $\mathrm{c1} 1^{\prime}-20 \mathrm{~L}$ & First fill for second distillation, $20 \mathrm{~L}$ of obtained distillate \\
\hline $\mathrm{c} 1^{\prime}-30 \mathrm{~L}$ & First fill for second distillation, $30 \mathrm{~L}$ of obtained distillate \\
\hline $\mathrm{c1} 1^{\prime}-40 \mathrm{~L}$ & First fill for second distillation, $40 \mathrm{~L}$ of obtained distillate \\
\hline c1'-50L & First fill for second distillation, $50 \mathrm{~L}$ of obtained distillate \\
\hline c1'-60L & First fill for second distillation, $60 \mathrm{~L}$ of obtained distillate \\
\hline $\mathrm{c} 1^{\prime}-70 \mathrm{~L}$ & First fill for second distillation, $70 \mathrm{~L}$ of obtained distillate \\
\hline $\mathrm{c1} 1^{\prime}-80 \mathrm{~L}$ & First fill for second distillation, $80 \mathrm{~L}$ of obtained distillate \\
\hline $\mathrm{c1} 1^{\prime}-90 \mathrm{~L}$ & First fill for second distillation, $90 \mathrm{~L}$ of obtained distillate \\
\hline c1'-100L & First fill for second distillation, $100 \mathrm{~L}$ of obtained distillate \\
\hline c1'-110L & First fill for second distillation, $110 \mathrm{~L}$ of obtained distillate \\
\hline c1'-120L & First fill for second distillation, $120 \mathrm{~L}$ of obtained distillate \\
\hline
\end{tabular}

points ranging from $78{ }^{\circ} \mathrm{C}$ to $121{ }^{\circ} \mathrm{C}$ (5). This part is called the heart, comprising most of the substances with a pleasant smell (aromatic esters and higher alcohols) (8). The alcoholic strength varies between 27 and 33\% vol. (first distillation) and between 60 and $70 \%$ vol. (second distillation). In the third fraction, the tail, are components of wine boiling from $128{ }^{\circ} \mathrm{C}$ to $223^{\circ} \mathrm{C}$, so-called fusel oils (4).
This article studied the different volatile compounds identified in the three fractions considering their influence on the final product.

\section{MATERIALS AND METHODS}

The raw material used to make the distillates was a mixture of two wines of Fetească albă and Fetească regală, 2015 millessime in the vineyard of Iaşi, Cetăţuia Monastery. The proposed 

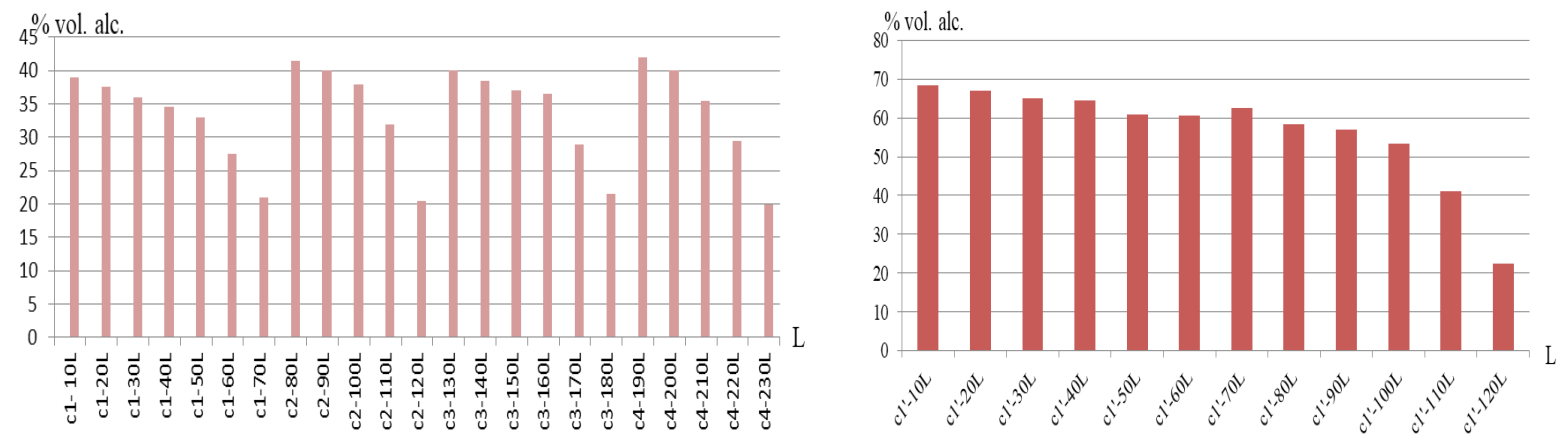

Fig. 1. Evolution of the alcoholic concentration during the first and second distillation

experimental protocol consisted of the double distillation of a volume of $1000 \mathrm{~L}$ of raw material. A simple copper distiller with a deflector was used. The distillator has a volume of 250 litres, so it was necessary to fill four times, resulting four series of each fraction: heads, heart and tails. From each $10 \mathrm{~L}$ of the distillate obtained, samples were collected, which were then subjected to gaschromatographic analyses. Both the heads and the tails were collected separately. Only the hearts were subjected to a second distillation.

35 experimental variants were obtained. The legend is presented in table 1 .

In order to assess the aroma fraction, a HS20GC-MS (head space extractor coupled to gas chromatography with mass spectrometer) was used (1). The system used as carrier gas the helium and the adsorption material for the stationary phase was the type of resin 2, 6-diphenylene oxide (TENAX). The results were processed qualitatively comparing them to different MS databases. Units of area (UA) were used to characterise the concentration of these compounds.

\section{RESULTS AND DISCUSSION}

The product obtained after the first distillation recorded an average alcoholic strength of 33.5\% vol., which increased after the second distillation, a final alcoholic concentration of $58.5 \%$ vol was obtained (Fig. 1).

The volatile alcohols identified in the analysed spirits can render pleasant or foul aromas to the final product. Therefore, it is important to know when they appear in order to keep or remove the fractions.

Isoamyl alcohol accounts for the largest proportion of the alcohol in the final distillate flavour (Fig. 2a). Because of its unpleasant smell, it is not desired in wine distillates. The largest amounts of this alcohol are identified in samples resulting from the primary process, the amount decreasing from heart to tails. Therefore, in order to improve the organoleptic qualities, it is necessary to remove the heads. During the second distillation, it recorded similar values, its presence not detected in the tail fraction. In order to diminish its effect, it is possible to eliminate the head, but some amount will remain, the negative influences of the aroma being smoothed over only by the process of aging (8).

Phenyl alcohol was identified in the samples obtained after the first distillation in low quantities, the largest amounts of it, as shown in figure $2 \mathrm{~b}$, detected in the heads. It is one of the compounds that offers pleasant aroma to the distillate. Smaller quantities of this alcohol, which will give a pleasant flavour to the distillate, will be preserved by keeping the heart fractions. During the second distillation, phenyl alcohol has different values, but in this case the highest amount found was in the tails.

Hexanol is a desirable compound in distillates, with positive influence on the flavour (sweet, green, and fruity) $(2,8)$. According to figure 2c, the largest amounts are registered in the heads and are extracted mainly in the first part of the process. As the transition from hearts to tails is made, there is a decreasing tendency. During the second distillation, hexanol was the only alcohol in the process identified in all samples and in considerable quantities. The smallest values were recorded in heads and tails.

Propanol is a compound that positively influences the sensorial profile of products. As is seen in figure $2 \mathrm{~d}$, this alcohol is extracted in the first part of the distillation process, small quantities of it being found only in the heads, which is why it is 

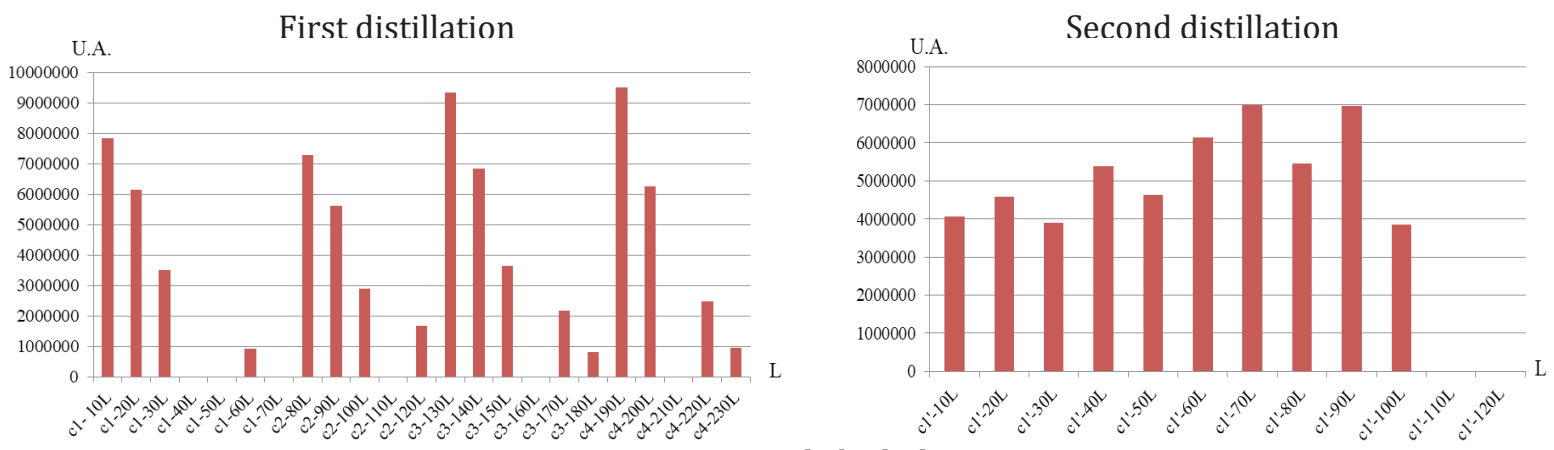

2a. Isoamyl alcohol
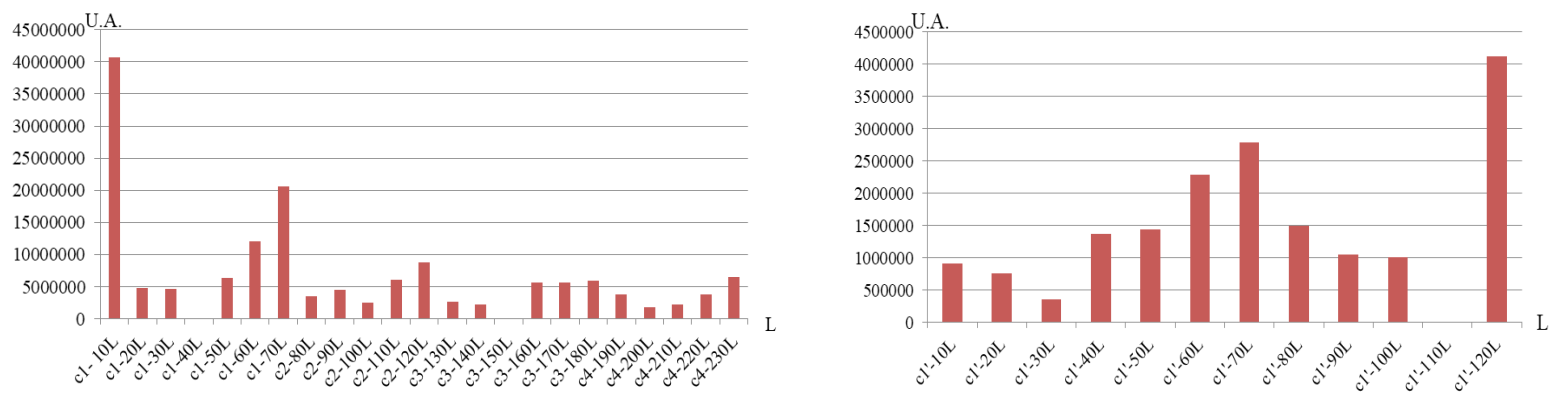

2b. Phenylethylalcohol
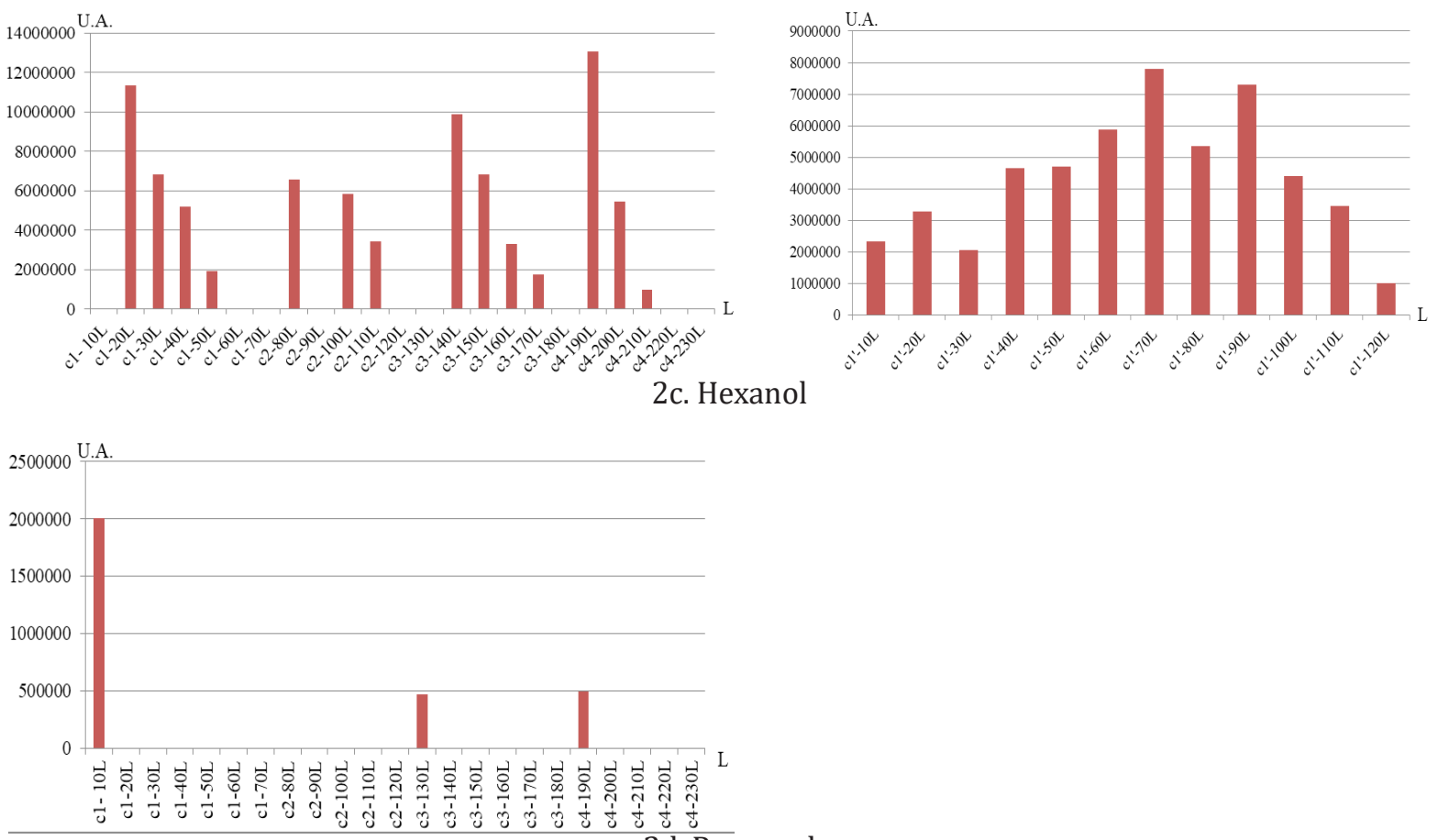

2d. Propanol

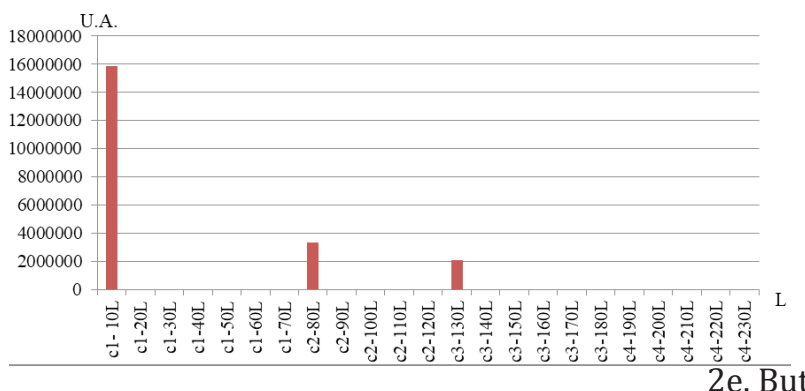

Butanol was identified in one sample, towards the end of the distillation process, but not in the tail, which makes it possible to keep it in view of its positive influence on the aromatic profile of the distillate. 

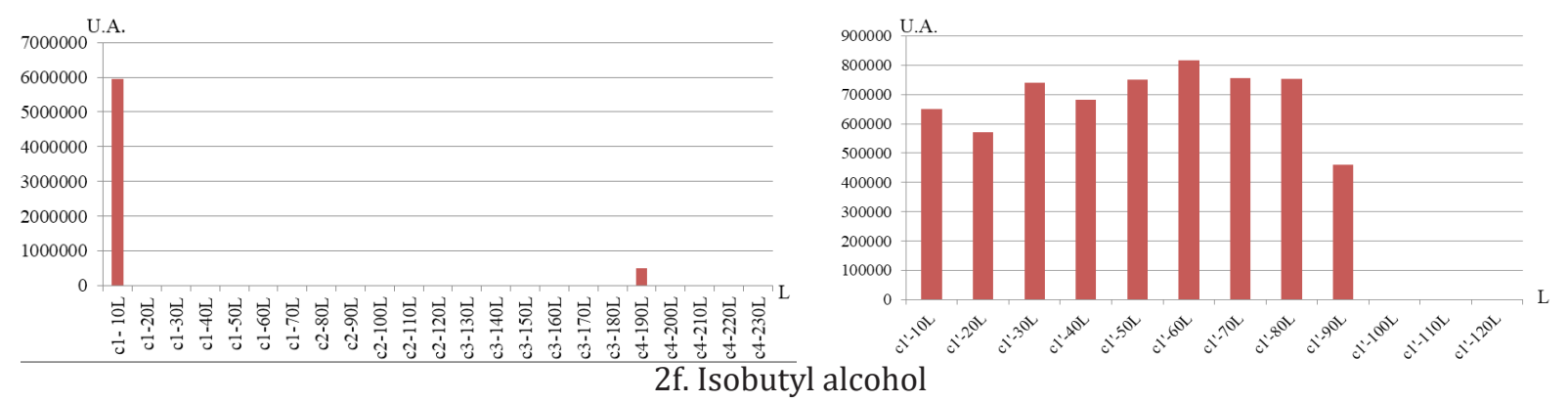

Fig. 2. Evolution of certain alcohols during first and second distillation process. a, b, c, d, e, findicate the specific alcohol

under the detection limit in the second distillation products.

Butanol is an organic compound with a pleasant, floral odour (2). As shown in figure 2e, this alcohol is only found in the heads, strongly decreasing from one boiler filling to another.

Isobutyl alcohol has negative influences on the distillate, imprinting its specific solvent smell $(2,4)$. However, it has been identified in very small quantities and only in the heads, so it will not have a very negative impact on the distillate and can easily be eliminated with the removal of these fractions. Isobutyl alcohol, in the second distillation, was identified in more samples and in larger quantities. The only fractions in which its concentrations recorded undetectable values were the tail and the fractions preceding it. Hence, significant amounts of it are extracted in the first stages of the distillation process. It is desirable to eliminate the fractions containing the highest amounts of this alcohol, given its negative impact on the organoleptic profile. In this regard, it is possible to do so only with the elimination of the heads, but also in this case, the highest amount of this alcohol will remain in the volume of the distillate for aging. In this situation, the only correction that can be applied to diminish its negative effect on the aromatic profile is the aging in oak or mulberry barrels, during which it is expected to be esterified with the formation of compounds that will positively influence the organoleptic characteristics.

The volatile acids found in the analysed distillate have a very important role, as most fatty acids render unpleasant aromas to the products $(2,3)$. However, most of them will be discarded during fractionated collection of the final produce or will be esterified during aging (9).
As it can be seen in figure $3 \mathrm{a}$, acetic acid, during both distillations, registers the largest amounts in the heads. At each refilling of the boiler, the amount of acetic acid produced in the distillate increases considerably. Values recorded in the other two fractions maintain a steady trend. It can be concluded that in order to remove the negative influence of the acetic acid flavour on the final product it is absolutely necessary to remove the head.

Octanoic acid is another acid-specific distillate obtained from wine, with a negative influence on its aroma (rancid). In this case, different quantities are recorded exactly opposite to acetic acid. In figure $3 \mathrm{~b}$, the highest concentrations of this acid are recorded in tails, during both distillations processes. Starting with the head fraction, where its concentrations record the lowest values and until the end, the tendency is slightly upward. The influence on the flavour of the final product is also a negative one, the taste of rancid being an undesirable one in the case of a future quality distillate. In this sense, it is advisable to collect the tails and remove them before the distillate is subjected to the aging process $(10,12)$.

Hexanoic acid is a fatty acid that confers to products a specific fat or rancid odour (10). Figure $3 c$ shows this acid recording high concentrations predominantly in the tail fraction. There is also an exception; a significant amount of this acid is encountered in the head fraction obtained at the distillation of the first boiler. To minimize the negative influence on the organoleptic characteristics, it is necessary to separately collect and remove the tails from the total volume of distillate for aging.

Decanoic acid confers to products a specific goat-like smell. The presence of decanoic acid is identified in few samples. In figure $3 \mathrm{~d}$ it can be seen 

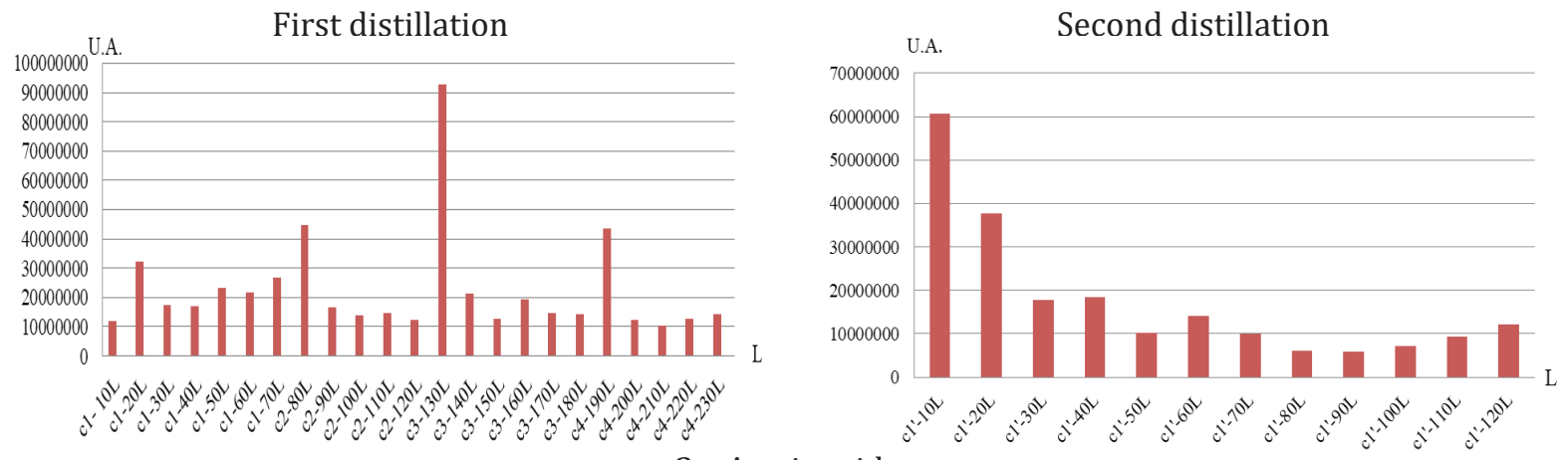

3a. Acetic acid
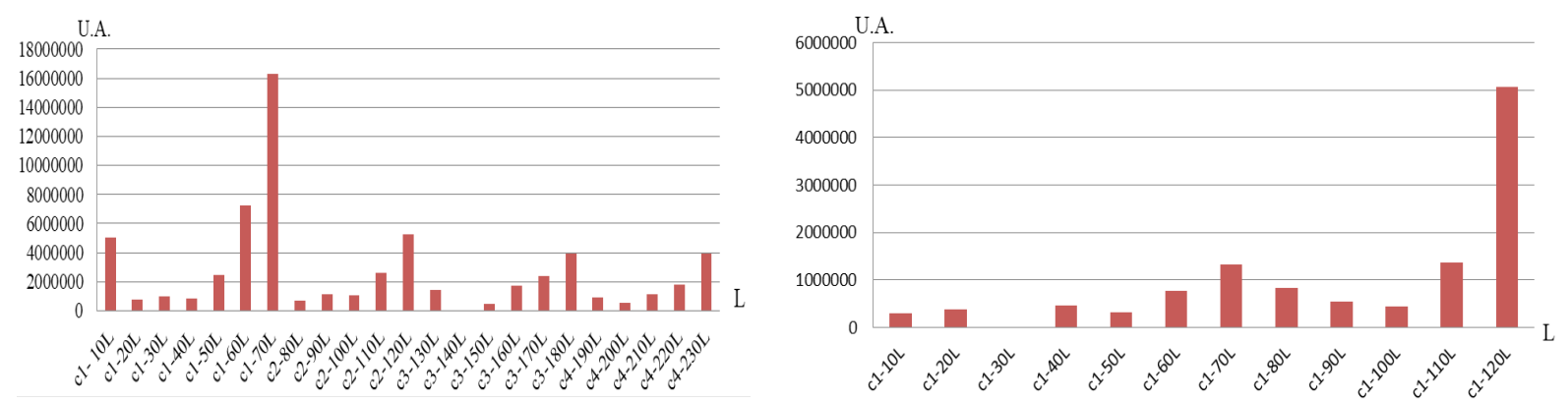

3b. Octanoic acid

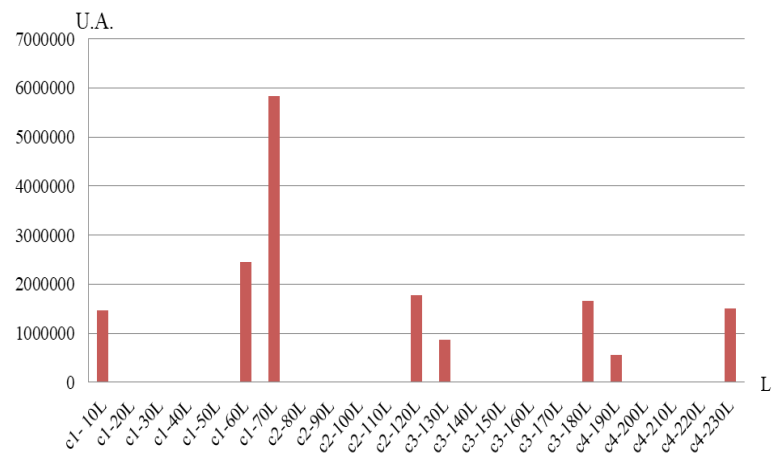

Hexanoic acid results in smaller quantities at the second distillation and only in one of the samples analysed in the last $10 \mathrm{~L}$ of the distillate collected.

This acid, as in the first distillation, is found mainly in queues.

3c. Hexanoic acid
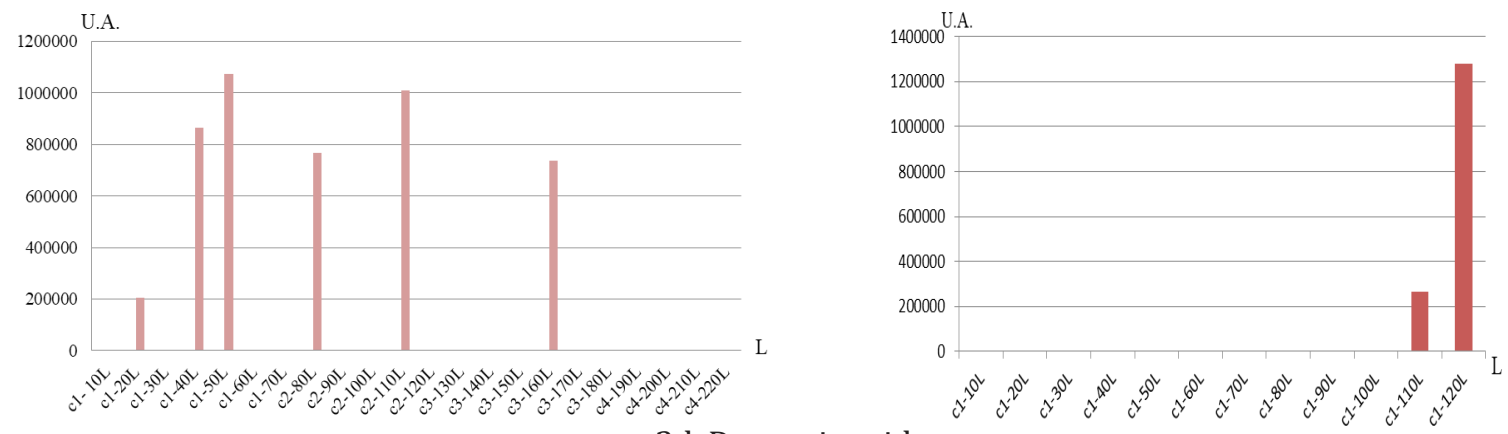

3d. Decanoic acid

Fig. 3. Evolution of certain acids during first and second distillation process. a, b, c, d indicate the specific acid

how the amounts of this acid are approximately constant throughout the first distillation process. During the second distillation, decanoic acid recorded a clear decrease, it is identified only towards the end of the distillation process. The amount detected in the fraction still in the heart is definitely lower than the one identified in the tail, an easy correction being applied. During the aging process in oak barrels (11), other flavour compounds will be formed to correct the organoleptic inconveniences conferred by this acid. 
Benzoic acid was identified only as traces (in a single sample and in very small quantities). This sample is obtained from the distillation of the first litres of wine. In this context, the most plausible explanation is that the acid was not extracted by distillation but was a residue on the machine. During the second distillation, benzoic acid was found to be under the detection limit, which reinforces the idea that its identification in a single sample at first distillation can only be due to impurity on the machine.

\section{CONCLUSIONS}

Concerning the acid profile, the following can be concluded: Acetic acid is an undesirable compound in the distillate obtained, its quantity being considerably diminished with the removal of the forehead fractions; octanoic, hexanoic and decanoic acids fall into the class of short chain fatty acids, adversely affect the organoleptic qualities of the substances they enter, but can easily esterify the resulting compounds giving pleasant odour. In this respect, it is recommended to age crude distillates in oak or mulberry barrels in order to achieve the maximum potential in terms of olfactory and taste qualities.

With respect to alcohols it has been found that among the seven alcohols which, due to the quantities in which they have been identified, can alter the aromatic profile of the distillate, can affect the distillate, imparting undesired taste or smells; on the other hand, the largest amounts have been identified in the fractions that will not be stored for aging, thus succeeding in eliminating them to significantly diminish and the negative impact of said alcohols on the organoleptic characteristics of distillate.
Acknowledgments. The authors would like to thank USAMV Iaşi for financial support and the Cetăţuia Monastery for providing the spirits samples for the analyses.

\section{REFERENCES}

1. Barry EF, Grob LR (2007). Gas chromatography. Ed. Wiley.

2. Burdock GA (2002). Fenaroli's handbook of flavour ingredients. Ed. CRC Press.

3. Coldea ET, Mudura E, Ranta N , Hădărean D (2013). The Impact of Grape Marc Distillation Process on the Major Volatile Compounds, Bulletin UASVM Animal Science and Biotechnologies 70(2), 223-229 Print ISSN 1843-5262; Electronic ISSN 1843-536X.

4. Coldea ET, Socaciu C, Pârv M, Vodnar D (2011). GasChromatographic Analysis of Major Volatile Compounds Found in Traditional Fruit Brandies from Transylvania, Romania, Notulae Botanicae Horti Agrobotanici ClujNapoca, 39(2): 109-116, Print ISSN 0255-965X; Electronic 1842-4309.

5. Cotea DV, Zănoagă C, Cotea VV (2009). Tratat de Oenochimie. Vol. 1, Editura Academia Română, București.

6. Gavrilescu I (1998). Cercetări privind stabilirea cadrului legislativ şi a condițiilor tehnologice pentru producerea distilatelor învechite de vin cu denumire de origine în România.

7. Holmyard EJ (1990) Alchemy. Courier Dover Publications.

8. Lafon R (1996). Le Cognac et sa distilation. Editura J. - B. Bailliere.

9. Pierre A (1894). Le vin et les vins de fruits. Analyse du mout et du vin. Vinification. Sucrage. Maladies du vin. Etude sur les levures de vin cultivées. Distilation. Ed. Gauthier-Villars.

10. Piggott JR, Peterson A (1989). Distilled beverage flavor: recent development. Ed. VCH.

11. Popa A (1985). Producerea şi învechirea distilatelor din vin. Ed. Scrisul românesc.

12. *** (1992). Le Bois et la Qualite Des Vins et Eaux-de-Vie, Vigne et Vin Publications Internationales (pp 81 - 89). 